\title{
Political Considerations of Controversial Medical Issues: Xenotransplantation and Society. A Presentation of the Work of the Norwegian National Working Group on Xenotransplantation
}

\author{
By Inger Lise Gjørv \\ Office of the Governor of the County of Nord-Trøndelag, N-7734 Steinkjer, Norway. \\ Tel: +47 74168022, Fax: +47 74168092, E-mail: inger-lise.gjorv@fm-nt.stat.no
}

\section{Introduction}

Based on recommendations of the Norwegian Government, the Storting decided a preliminary prohibition against any medical treatment of humans with the use of biological material from animals in 1999. This moratorium should be in effect until 01.01.2003. During this time the issue of xenotransplantation, with its many problems and controversies, should be thoroughly elucidated and debated.

A xenotransplantation working group was established in April 2000 as a consequence of this decision, and in many ways I think that the composition of this group was decisive for the final conclusion. The members of this group were chosen from a wide range of expert areas in society, such as law, human and veterinary medicine, ethics and animal welfare and risk management. The chairwoman of this working group, and the author of the current paper, owned experience from a political career at a national level, and I am currently the governor of the county of Nord-Trøndelag, Norway. In the following paper the work of this group will be presented. This paper addresses the media reactions, the political considerations and decisions, further development and the preliminary conclusions regarding the issue of xenotransplantation in the Norwegian society.

\section{The working group}

The names of the members of the working group are:

Chairwoman, Governor of the County of Nord-Trøndelag, Norway: The author Ms. Inger Lise Gjørv

\section{Members:}

- Ombudsman for patients: Ms. Grethe Brundtland, Hordaland,

- Veterinarian, Dr. med. vet. Ms. Bergljot Børresen, Oslo

- Medical doctor, Prof. dr. med. Mr. Odd Geiran, Rikshospitalet (National Hospital, University of Oslo)

- Professor of theology, Prof. dr. theol. Mr. Gunnar Heiene, Det teologiske menighetsfakultet (the Norwegian Lutheran School of Theology)

- Professor of ethics, Prof. dr. phil. Mr. Matthias Kaiser, Den nasjonale forskningsetiske komité for vitenskap og teknologi ( National Ethics Committee in Science and Technology)

- Medical Doctor, Prof. dr. med. Mr. Tore Midtvedt, Karolinska Instituttet, Stockholm, Sweden.

- Veterinarian, Prof. dr. scient. Mr. Espen Rim- 
stad, Norges veterinærhøgskole (Norwegian School of Veterinary Science)

- (High Court judge) Lagdommer Ms. Nina Mår Tapper, Frostating lagmannsrett, (Frostating High Court)

- Medical doctor, Prof. dr. med. Mr.Tom Eirik Mollnes, University of Tromsø

It is obvious from this list of names that the members of the working group altogether possessed a wide and thorough knowledge on the subjects that the working group had to discuss as directed by its mandate. However, hindsight revealed that the legal issues related to the subject of xenotransplantation were so extensive and complicated to understand for lay people, that it would have been a great advantage to have another lawyer amongst the members of the working group. Despite a tremendous amount of work carried out by the high court judge Nina Mår Tapper, the group was not able to complete a written proposition to an Act regulating the issue of xenotransplantation. However, the group provided extensive and accurate descriptions of what should be the contents of such an Act.

\section{Excerpts from the committee's work}

The Swedish government had already initiated the formation of a committee on xenotransplantation prior to the establishment of the Norwegian group, and its work was completed with a printed report (1). The immediate reaction from the Norwegian group was that the work was already completed. However, it was later evident, that the way of working, and partly also the conclusions of our group, turned out differently from those of the Swedish group. Maybe the results came out differently because of different traditions between the two countries in the organisation and working procedures within such committees. The Swedish committee chose another approach to the subject based on a more politically influenced working group with sev- eral nationally active politicians participating, and by carrying out a wide opinion poll on people's attitudes towards xenotransplantation. Thus the Swedish committee became more politically oriented in their evaluation than the Norwegian group.

The conclusions of the Norwegian group were primarily based on discussions among the people within the working group. However, within its frames of reference, the Norwegian working group also started their work with relatively rigid presumptions and opinions on what should be the conclusions. This often occurs when strongheaded individuals from different environments, and with different professional backgrounds, are assembled to discuss a matter of great importance and controversy. But it soon appeared that the members of the working group were able to overcome the obstacle of predisposed points of view, and with enthusiasm, they dove deeply into the sea of current puzzles and scientific challenges of the mandate. This may be one of the reasons why, contrary to most people's expectations, the conclusion was unanimous. Another point, which contributed to the very solid unanimity, is the angle of approach chosen by the group as the work went along. I will describe it through the following 6 points:

1. The medical problems, to which there are yet no solutions, will eventually be solved. Xenotransplantation will follow, and if not allowed in Norway, other countries will allow it.

2. The largest risk is not to the individual, i.e. that of the single patient who receives an animal organ. The greatest risk is collective, i.e. that of not being able to protect society against the effects of xenozoonoses, and thereby facing the challenge of new epidemical diseases.

3. National borders cannot prevent the spread of these diseases 
4. One cannot prevent Norwegian citizens from going abroad to have organs transplanted into them, and subsequently, from returning to Norway, thereby posing a potential risk for disease transmission also in Norway.

5. Nothing is gained from isolating ourselves from the international scientific world. One may even go so far as to ask, whether it is ethically acceptable to harvest the progress of science obtained by other nations without contributing to this development.

6. Norway is an integrated part of the world community. Research, disease and responsibility are universal cognisance.

With these principles the working group concentrated on professional questions, and the report was, at the time it was issued, a well updated review of the state of the art of xenotransplantation in Norway, and to the extent that the sources were available and reliable, also internationally. The report was published on June 20th 2001 (2). The primary conclusion was that the moratorium was to cease on January 1st 2003. However, the group recommended that an interim organ should be established with its primary mandate to supervise the development of the xenotransplantation issue internationally, and also, to offer advice to the Government on necessary actions to be carried out as a result of this development.

\section{Public concern and political consequences}

At the time of publication of the report the public reactions to its conclusions (and thus the political interest) were actually limited. The explanation to this is probably that the media normally prefer to focus on conflict areas, and the conclusions of the working group were unanimous, and thus did not give rise to conflict. Citations from declarations made by the theological member of our group, such as " Hu- man dignity is not compromised by a human carrying a pig heart", probably also further dampened the potential hazard for public uproar.

The work of the committee was then, as is normal procedure in Norway, sent through an official hearing in relevant milieus. A total of 47 written statements were returned to the group, of which 38 were supportive of the suggestions made by the committee, while the remaining wished to continue the moratorium, so that the problems related to xenotransplantation could be further elucidated.

The Government sent the proposal to the Storting in 2002 along with a recommendation to extend the moratorium until January 1, 2005. The parties represented in the current Government, Høyre (Liberal Conservative Party), Venstre (Left wing Liberal Party) and Kristelig Folkeparti (Christian Democrats) supported this proposal. In addition support was obtained from the Sosialistisk Venstreparti (Socialist Left Party). The representatives of Arbeiderpartiet (Labour Party) thought it unnecessary to prolong the moratorium and wanted a proposition for an Act on Xenotransplantation as soon as possible. Fremskrittspartiet (Party of Progress) had one special remark, but in principle, this party went along with the view of the Arbeiderpartiet.

The debate in the Storting was relatively undramatic, and Fremskrittspartiet and Sosialistisk Venstreparti represented the opposite extremes. Sosialistisk Venstreparti strongly pointed out the risk for xenozoonoses and unknown viruses as a collective risk. Fremskrittspartiet debated that this risk was minimal, and that the treatment of the single human being should be a priority.

However, "for and against" xenotransplantation was never debated, neither were the suggested surveillance actions.

Stortinget unanimously supported the estab- 
lishment of an interim organ, which will supervise the rapid international development of xenotransplantation. One decisive argument to prolong the moratorium was to await the decision of the European Parliament. The Parliament Assembly stated that xenotransplantation should not be carried out in any of the member states until regulated by law. The Norwegian Government wished to await the recommendations from the Minister Committee. The Minister Committee is expected to conclude its work this autumn (2002).

At the moment one may conclude the state of the situation as follows; the politicians are adopting an awaiting attitude, whereas the scientists are quietly carrying on with their business.

\section{Further recommendations of the working group}

As previously mentioned, the issue raised little debate or resistance against the resolutions of the working group concerning an Act on xenotransplantation with directives. I will introduce some of these in the following paragraphs:

The working group based it conclusion on the precautionary principle and advocated that a strict regulation is needed to protect society against the hazards connected with xenotransplantation. The individual rights of the patients and the animal welfare issue must also be addressed.

The working group conclusions emphasize the urgent need for a Xenotransplantation Act. This Act should regulate all clinical research and treatment. And it should also harbour regulations of actions that may be necessary, including the mandatory actions related to surveillance of the health state of the xenotransplanted patient.

The group also recommended the establishment of a special Advisory board for xenotransplantation, which should supervise the development of xenotransplantation internationally, and based on this development, the Board should offer advice to the Ministry on topics related to xenotransplantation.

All applications of clinical trials and the institution of medical treatment, which involve xenotransplantation, should be sent to the Advisory board on xenotransplantation for comments on these issues. Further, the Advisory board should continuously be updated on the xenotransplantation development and enterprise, the institutions involved therein, and should stimulate the public debate on essential aspects of xenotransplantation. The members of the Advisory board should be appointed by the Ministry, however remain independent thereof, and should not be instructed by any governmental body. The tasks of the Advisory board require professional competence as well as layman's perspective and representation.

A central register of xenpotransplantations should be established. Clinical laboratory based recording of xenotransplant recipients is mandatory to detect at the earliest time possible, and to stop any introduction of contagious material that may lead to xeno-induced zoonoses. A health register for xeno-recipients should also be established.

A special xenobiobank based on blood and tissue samples, micro-organisms, biological material from donor animals, from patients who received animal organs, and even from the patients' close contacts, such as household members and relatives, should be established. This biobank should be available for retrospective analysis and epidemiological tracking of transmissible diseases that may be connected to xenotransplantation. Internationally, recommendations have been put forward to conserve these samples for at least 50 years.

To be able to receive an offer of treatment by means of xenotransplantation the patients have to agree to lifelong surveillance with respect to 
risk of disease transmission, and the patient cannot withdraw from this mandatory surveillance ever. The follow-up of these patients involves regular health checks, inclusion in the xenotransplantation register, and collection and conservation of biological samples from the patients in the xenobiobank. Also, the patients must agree to an eventual autopsy.

All restrictions mentioned above, require special conditions for informed consent. Close relatives of the patients should be informed in writing, since this may also directly influence their lives due to the mandatory surveillance program. The working group was also concerned about the animal welfare aspect, since production of source animals may require special conditions for breeding and rearing of these animals.

\section{Conclusion}

I now presume that, after the processing in the Storting possibly during 2003, these actions are to be prepared by an interim organ for xenotransplantation, which both the government and the Storting have accepted. In short, all of us that are fascinated by this exciting issue, are facing challenging times both in Norway and internationally in the near future, since the science and skill of xenotransplantation is developing rapidly.

\section{References}

1. From one species to another - transplantation from animals to humans. A report by the Swedish Committee on Xenotransplantation. Swedish Government Official Report No 199, 120, 1-40.

2. Xenotransplantation:medical use of live cells, tissues and organs from animals. NOU 2001, 18, Ministry of Health, Oslo, Norway. ISSN:003332306. 